
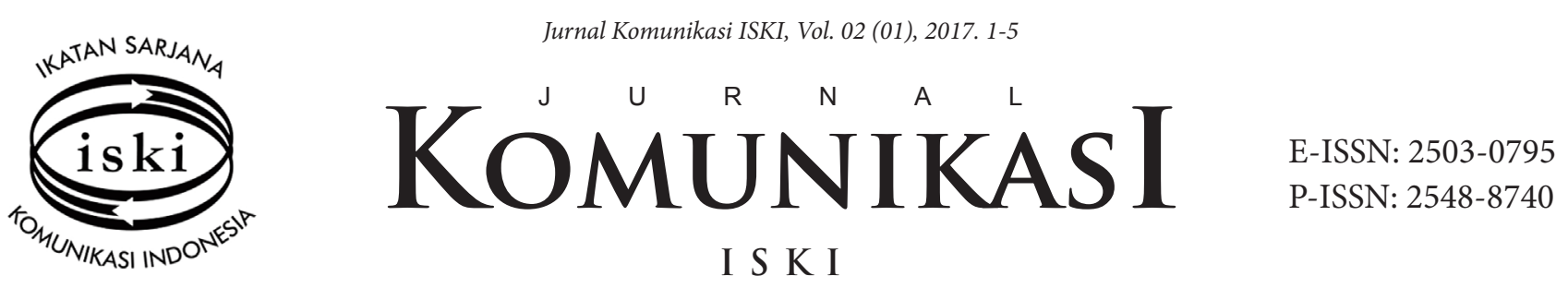

\author{
I S K I
}

\title{
Media Propaganda Techniques in the South China Sea Dispute
}

\author{
Cheryl Pricilla Bensa ${ }^{1}$ and Lupita Wijaya ${ }^{2}$ \\ ${ }^{1.2}$ Faculty of Communication, Universitas Multimedia Nusantara \\ Jl. Scientia Boulevard, Tangerang Selatan, Banten 15810, Indonesia \\ ${ }^{1}$ cheryl@umn.ac.id, ${ }^{2}$ lupita@umn.ac.id
}

\begin{abstract}
Bilateral relationship between Indonesia and China which is a pivotal pathway to Global Maritime Axis's foreign policy has been relentlessly addressed by President Joko Widodo since his early administration in 2014. However, Indonesia is aware that China's claim of nine-dashed line (9DL) has overlapped with Indonesia's sovereignty area, Natuna water. This territory dispute has pushed Indonesian government to take a decisive action by sending a verbal note protest to the Chinese embassy in Indonesia. In the perspective of international communication, this action has scrutinized the interdependence between media systems and political systems as a form of a symbiosis connecting and creating perceptions on the issue. Propaganda techniques of mass media, such as inter alia, namecalling, glittering generality, transfer, plain folks, testimonial, selection, bandwagon, and frustration of scapegoat, might create certain perceptions. This study maps the propaganda techniques by Indonesian high-circulated newspaper Kompas and China's state-run media Xinhua news agency. This study applies quantitative content analysis method in the period of May 30 to July 30, 2016.
\end{abstract}

Keywords: South China Sea, Media, Propaganda Technique, Quantitative Content Analysis

\begin{abstract}
Abstrak
Hubungan bilateral Indonesia-Cina merupakan hal fundamental dalam implementasi kebijakan luar negeri Indonesia yang dikenal dengan Poros Maritim Dunia. Meskipun demikian, Indonesia tidak bisa memungkiri bahwa sebagian besar wilayah konflik Laut Cina Selatan dalam nine-dash line (9DL) memiliki tumpang tindih wilayah dengan wilayah Indonesia. Konflik terbuka pada tahun ini antara Indonesia dan Cina menuai protes keras dari Indonesia yang disampaikan melalui protes resmi langsung ke kedutaan besar Cina di Indonesia. Dari sisi komunikasi, hal ini dianggap penting karena media dan sistem politik internasional merupakan sebuah simbiosis yang menghubungkan dan membentuk pandangan terhadap isu tersebut. Pandangan tersebut salah satunya dibentuk oleh propaganda media massa. Dalam studi komunikasi internasional, teknik propaganda media terbagi menjadi delapan, yaitu name calling, glittering generality, transfer, plain folks, testimonial, selection, bandwagon, dan frustration scapegoat. Penelitian ini akan memetakan teknik propaganda yang digunakan oleh media massa dari Indonesia dan Cina, yaitu Harian Kompas dan Kantor Berita Xin Hua. Metode penelitian yang digunakan adalah analisis isi kuantitatif dalam periode 30 Mei hingga 30 Juli 2016.
\end{abstract}

Kata Kunci: Laut Cina Selatan, Media, Teknik Propaganda, Analisis Isi Kuantitatif 


\section{Introduction}

Bilateral relationship between Indonesia and China has rather been stable since Indonesian independence. During Indonesian post-independence, this bilateralism has been established in 1950 after Indonesia recognized the establishment of China as a country under a communist government (Gitosardjono, 2006). Post-election of 1957 in Indonesia, the great power of PKI (The Communist Party of Indonesia) which was regarded as a threat and the estrangement between Indonesia and China began (Adriansyah, 2005). Following the beginning of the New Order of Soeharto in 1967, Indonesia stopped the trade relations with China. However, after the Reformation Era, the diplomatic relations between the two countries have increasingly improved during the term of President Abdurrahman Wahid (Sinaga, 2010). It is followed by the cooperation between the two countries in the sector of energy during President Megawati Soekarnoputri's term. A Declaration of Strategic Partnership between Indonesia and China was formed under the government of Susilo Bambang Yudhoyono on April 25, 2005. It has developed into cooperation between the two countries through the ACFTA (ASEAN-China Free Trade Agreement). Moreover, the cooperation between Indonesia and China has also been manifested in the involvement of two countries in global organizations such as G-20 and WTO (World Trade Organization) (Rachmayanti, 2014).

Lately, there are several problems arising along with the development of cooperation between Indonesia and China. The South China Sea dispute raises tensions in Asia Pacific region. Several islands in the area such as Spartly and Paracel create tensions leading to the geopolitical instability among six countries, namely Malaysia, the Philippines, Brunei Darussalam, Vietnam, Taiwan, and China.

In early 2015, the two countries have developed their relations by signing economic cooperation in various sectors including infrastructure, investment, and trade. Since the beginning of 2016, there have been several incidents concerning traditional maritime boundary between Indonesia and China. However, the government of Indonesia insists that Indonesia will not be involved in the South China Sea dispute.

As a country implementing an independent and active foreign policy, Indonesia takes the role of peacemaker for the South China Sea dispute. Eventu- ally, at the same year, China proposed a verbal note to the United Nations, better known as the nine-dash line or $U$ line, as a continuation of the territorial claims of the South China Sea (Kusumadewi, 2016). This proposal has actually been incorporated in the official map of the Communist Party of China in 1953 (Dema, 2016). A region of Indonesia -- namely $\mathrm{Na}-$ tuna Island, is one of the territories claimed in the $\mathrm{U}$ line. Furthermore, China has also been at conflict with the government of Indonesia over illegal fishing since several Chinese fishing boats have stolen fishes in Indonesian seas. In several incidents, Chinese fishing boats have been caught in the waters of Natuna in 2010. The last one was arrested in May 2016 (BBC Indonesia, 2016).

The Minister of Maritime Affairs and Fisheries Susi Pudjiastuti, through the Minister of Foreign Affairs, Retno LP Marsudi, states that Indonesia has given a strong protest and memoranda of violation issued by the coast guard that China has violated the sovereign and jurisdictional rights of Indonesia (Daniel, 2016).

This conflict has not been resolved yet and diplomatic accusations have begun. Although Indonesia adheres to independent and active foreign policy, it is difficult to remain neutral since the arrest of Chinese boats in the Natuna waters. In addition, there has been a pressure from many parties that this is the right time for Indonesia to be assertive about its maritime boundary, apart from economic and diplomatic relations with China.

Moreover, President Joko Widodo declares an Indonesian foreign policy -- "Global Maritime Axis". This policy is a review on the development of a national agenda to re-expand the maritime culture of Indonesia in various sectors, including economy. In his speech at the East Asia Summit in Nay Pyi Taw, Myanmar, Joko Widodo emphasized that Indonesia will be the axis of the maritime world.

Bilateralism between the two countries is inseparable from the media coverage, both in Indonesia and China. In terms of communication, it is considered as important because media and international political system form a symbiosis, connecting and creating perceptions on the issue. Propaganda of mass media creates certain perceptions. This study will examine the propaganda techniques used by the mass media both in Indonesia and China. This study will focus on Harian Kompas from Indonesia and online news of Xinhua News Agency from China. In the study 
of international communication, media propaganda techniques are divided into name-calling, glittering generality, transfer, plain folks, testimonial, selection, bandwagon, and frustration of scapegoat (Uni Assignment Centre, 2013).

\section{Theoretical Framework}

Propaganda is taken from the Latin word propagare meaning "to spread, to expand". Propaganda has been used since medieval era to describe the missionary activity of Roman Catholic Church. During the Age of Enlightenment, the intellectuals saw propaganda as something hidden and dangerous by deceiving people and made them do things contrary to their will and interests (Kaid \& Bacha, 2008: 659).

Propaganda is a communication technique seek- ing to manipulate the attitudes and opinions of audienceas target. Propaganda activities are aimed to change the existing belief system, value structure, and political position to produce a certain attitude to agree with the propagandists regarding an issue thereof. The target of propaganda is the public, therefore, it requires the mass media (speeches, advertisements, editorials, articles, music, or posters) as the messenger (Kaid \& Bacha, 2008: 658). In general, propaganda is not a foreign term since the media has used it frequently. Propaganda is often referred to as rhetoric, spin doctoring, indoctrination, agitprop (propaganda through literature, drama, music or art), or brainwashing (Cunningham, 2002).

Kamalipour \& Snow (2004) mentioned that the two elements of information dominance compared to

Table 1

Eight Media Propaganda Techniques

\begin{tabular}{|c|c|c|c|}
\hline No. & Technique & Definition & Example \\
\hline 1. & Name Calling & $\begin{array}{l}\text { A tactic to ensure the target receives a conclusion without deep } \\
\text { consideration of the facts. It uses words, relating to a person or an } \\
\text { idea to a negative concept. }\end{array}$ & $\begin{array}{l}\text { Propagandists call their } \\
\text { opponents "instigators", } \\
\text { "deceiver" or "terrorist". }\end{array}$ \\
\hline 2. & Glittering Generality & $\begin{array}{l}\text { A tactic to seize the emotions and ensure the target followed } \\
\text { by the "solidarity" and the propagandists by using highly valued } \\
\text { concepts and beliefs ensuring the audience feels positive and by } \\
\text { inviting a big round of applause. }\end{array}$ & $\begin{array}{l}\text { Indonesia is a democratic } \\
\text { country! }\end{array}$ \\
\hline 3. & Transfer & $\begin{array}{l}\text { Improving an image by associating the product with the symbols } \\
\text { respected by the community. It stimulates the recipients to identify } \\
\text { themselves with those authorities. }\end{array}$ & $\begin{array}{l}\text { The cartoon of Uncle } \\
\text { Sam who represents } \\
\text { the consensus of public } \\
\text { opinion. }\end{array}$ \\
\hline 4. & Testimonial & $\begin{array}{l}\text { The use of famous figures (actors/actresses/ politicians) to } \\
\text { advertise the candidates/products. Testimonial has great appeal to } \\
\text { emotions instead of logic because it gives a weak justification for a } \\
\text { product/action. }\end{array}$ & $\begin{array}{l}\text { Oprah Winfrey supporting } \\
\text { Obama to be the } \\
\text { President. }\end{array}$ \\
\hline 5. & Plain folks & $\begin{array}{l}\text { A trick putting propagandists as ordinary people like the target } \\
\text { audience to demonstrate the ability to empathize and understand } \\
\text { the concerns/feelings of the public. }\end{array}$ & $\begin{array}{l}\text { Maspion is produced } \\
\text { by Indonesia. Use } \\
\text { Indonesian products. }\end{array}$ \\
\hline 6. & $\begin{array}{l}\text { Card Stacking/ } \\
\text { Selection }\end{array}$ & $\begin{array}{l}\text { A propaganda technique conducted by selecting statements based } \\
\text { on certain events or by using selective facts to support its interests } \\
\text { or to prove the prior statements. }\end{array}$ & $\begin{array}{l}\text { The negative effect of the } \\
\text { free market. }\end{array}$ \\
\hline 7. & Bandwagon & $\begin{array}{l}\text { Psychological perspective explains that most people tend } \\
\text { to choose to be the majority rather than the minority. The } \\
\text { propagandists suggest to the audiences that they will lose or miss } \\
\text { something by not moving with the others. It manipulates fear and } \\
\text { insecurity. }\end{array}$ & $\begin{array}{l}\text { "Since everyone is doing } \\
\text { it, you should too." }\end{array}$ \\
\hline 8. & $\begin{array}{l}\text { Frustration of } \\
\text { Scapegoat }\end{array}$ & $\begin{array}{l}\text { Looking for someone to blame for the mistakes of others. When a } \\
\text { problem occurs, people will tend to blame others. Therefore, they } \\
\text { will look for a scapegoat. Scapegoat is also an easy way to create } \\
\text { resentment and frustration. }\end{array}$ & $\begin{array}{l}\text { "It is all because of him/ } \\
\text { her." }\end{array}$ \\
\hline
\end{tabular}


the traditional concept of propaganda. First, the integration propaganda and psychological operations become the wider concept of information warfare. The traditional concept of propaganda involves the creation and distribution of messages through the government-owned media or independent media.

In 1937, a study conducted by the Institute for Propaganda Analysis has identified seven propaganda techniques, namely name-calling, glittering generality, transfer, testimonial, plain folks, card stacking (selection), and bandwagon. Testimonials and frustration of scapegoat are then added into the propaganda techniques by Holsti (Uni Assignment Centre, 2013), bringing the total of eight propaganda techniques mapped in the following table.

For most people, the term propaganda has a negative connotation. During the 1920s, the term 'public relations' was used as the substitute. Apart from the use of the term, propaganda cannot be circumvented in the 1930s in the United States, from radio ads to pro-government or anti-fascist messages through the film, columns of newspapers, political figures, religious leaders and celebrities (Hobbs \& McGee, 2014).

\section{Material and Methodology}

This study is a quantitative content analysis. Kerlinger (1973) defines it as a systematic, objective and quantitative process for the purpose of variable of measurement. In this study, the author wants to find out propaganda techniques performed by the mass media in Indonesia (Harian Kompas) and China (Xinhua News Agency). The population in this study is the entire news relevant to the South China Sea, including the problem of illegal fishing in Natuna Islands published in Harian Kompas and Xinhua News Agency in a two-month period from May 30 until July 30,2016 . This period is chosen because there was an illegal fishing carried out by Chinese boats at the end of May. The keywords used are "the South China Sea" and "Indonesia." This study uses a total sampling, namely the entire population of the news from May 30 to July 30, 2016. There are 66 news articles from Harian Kompas and another 10 from Xinhua News Agency.

\section{Result and Discussion}

The results of analysis of 66 news articles from Harian Kompas and 10 news articles from Xinhua News Agency are as follows.
Figure 1 The Result from Harian Kompas

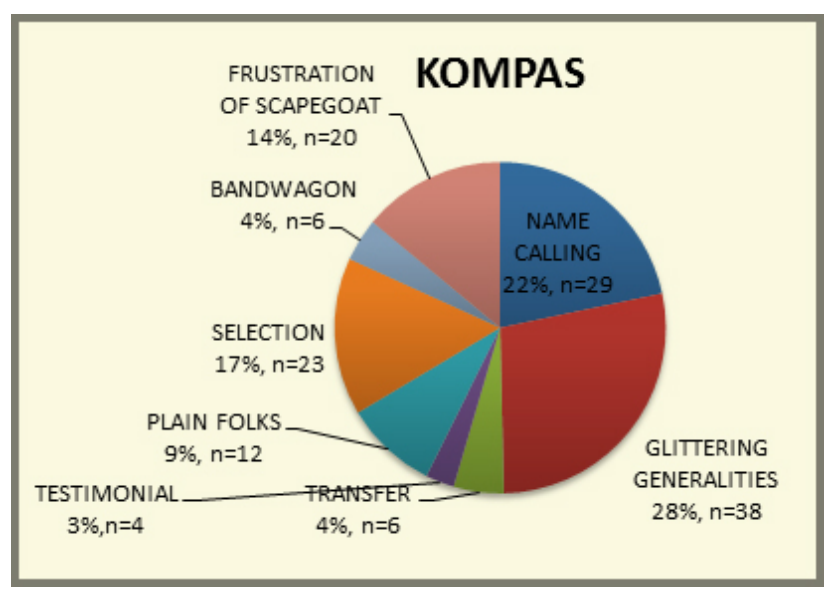

Figure 1 shows propaganda techniques used in the news about the South China Sea by Harian Kompas. The highest percentage is glittering generalities for $28 \%(\mathrm{n}=38)$. The second is name calling for $22 \%(\mathrm{n}=$ $29)$. The third is selection for $17 \%(n=23)$.

Figure 2

The Result from Xinhua

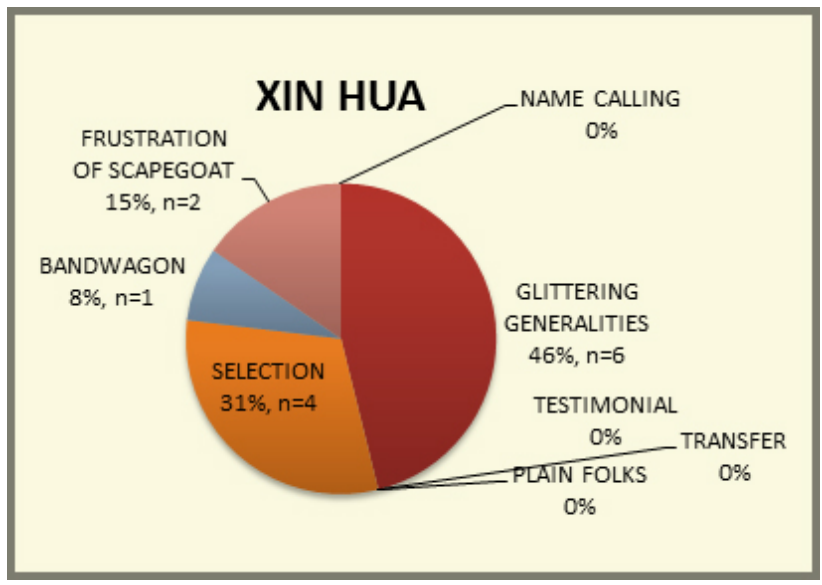

Figure 2. shows propaganda techniques used in the news about the South China Sea by Xinhua News Agency. The highest percentage is glittering generalities for $46 \%(n=6)$. The second is selection for $31 \%(n$ $=4)$. The third is scapegoat frustration for $15 \%(n=2)$, followed by bandwagon for $8 \%(n=1)$.

The propaganda techniques widely used by Harian Kompas are glittering generalities, name calling, and selection. Glittering generalities are most commonly depicted by looking at Indonesia as a big country that has an important role in the Asia Pacific region. For example, "Indonesia bangsa tangguh" in the article "Ini Soal Kedaulatan, Bung!". Name calling 
technique is most commonly found by connecting the overlapping region with the concept of colonialism or maritime hegemony, for example, the use of maritime colonialism in the article "Perilaku Ambiguitas Memicu Konflik Militer" and hegemony in the article "Tantangan Diplomasi Indonesia di Kawasan Sarat Sengketa." Selection technique is commonly found in a variety of major themes, particularly regarding the defense of the Republic of Indonesia, by selecting issues of the South China Sea.

The propaganda technique commonly used by Xinhua News Agency is glittering generalities. One of the examples is reflected in the statement, "China and ASEAN countries should work together to maintain peace and stability in the South China Sea" in the article "Page of South China Sea arbitration has been turned over: Chinese PM."Xinhua News Agency promotes highly valued concepts maintaining the approach of diplomacy for peace.

\section{Conclusion}

The findings of quantitative content analysis show that media propaganda techniques used by both media in the South China Sea dispute are glittering generalities.

Harian Kompas emphasizes the importance of Indonesia's role in the dispute in South China Sea as a formidable side and the peacemaker. In Xinhua News Agency, this tactic is shown through highly valued concepts promoting diplomacy for peace between China and ASEAN.

Based on the study, we will provide methodological and practical recommendations for future studies. The methodological advice is to expand the population for the future studies. The practical advice is for journalists to make the news in accordance with the principles of journalism (covering both sides and objectivity) without using a propaganda technique.

\section{References}

Adriansyah, Eddy. (2005). Pasang Surut Hubungan RI-RRC. Retrieved August 19, 2016, from www. osdir.com $/ \mathrm{ml} /$ culture.region.china.budayationghoa/2005-09/msg.html.

BBC Indonesia. (2016). Ditangkap AL Indonesia, Delapan ABK Asal China Jalani Proses Hukum. Retrieved August 19, 2016, from http://www.bbc. com/indonesia/berita_indonesia/2016/05/160529_ indonesia_kapal_cina_natuna_tahan.

Cunningham, S. B. (2002). The Idea of Propaganda: A
Reconstruction. Westport: Greenwood Publishing Group.

Daniel, Wahyu. (2016). Tanggapan Kedubes China terkait Protes Indonesia di Kasus Pencurian Ikan. Retrieved August 19, 2016, from http://news.detik. com/berita/3169738/tanggapan-kedubes-chinaterkait-protes-indonesia-di-kasus-pencurian-ikan.

Dema, Apiyon. (2016). Ini Perjalanan Sengketa Kawasan Laut Cina Selatan.Retrieved August 19, 2016, from https://m.tempo.co/read/news/ 2016/07/ 12/118787130/ini-perjalanan-sengketa-kawasanlaut-cina-selatan.

Uni Assignment Centre, UK. (November 2013). The Role of China Press Media Essay. Retrieved from http:// www.uniassignment.com/essay-samples/media/ the-role-of-china-press-media-essay.php?cref $=1$.

Gitosardjono, Sukamdani Sahid. (2006). Hubungan Indonesia Tiongkok di Era Kebangkitan Asia. Association of China-Indonesia Economic, Social and Cultural Cooperation.

Hobbs, R., \& McGee, S. (2014). Teaching about propaganda: an examination of the historical roots of media literacy. Journal of Media Literacy Education, 6(2), 5.

Kaid, L. L., \& Holtz-Bacha, C. (Eds.). (2008). Encyclopedia of Political Communication. London: SAGE Publications.

Kamalipour, Y. R., \& Snow, N. (2004). War, Media, and Propaganda: A Global Perspective. Oxford: Rowman\& Littlefield.

Kerlinger, N. F. (1973). Foundations of Behavioral Research. New York: Holt, Rinehart and Winston.

Kusumadewi, Anggi. (2016). Perairan Natuna, 'Medan Tempur' Indonesia-China. Retrieved August 19, 2016, from http://www.cnnindonesia.com/ nasional/20160620170157-20-139564/perairannatuna-medan-tempur-indonesia-china/.

Sinaga, Lidya Christin. (2010). Memaknai Tahun Persahabatan Indonesia-Cina. Retrieved August 19, 2016, from http://www.politik.lipi.go.id/kolom/324memaknai-tahun-persahabatanindonesia-cina. html.

Rachmayanti, Nahdia (2014). Dinamika Hubungan Bilateral Indonesia-China (Tiongkok) Pada Era Pemerintahan Presiden Susilo Bambang Yudhoyono (2004-2013). Retrieved August 19, 2016, from https://www.academia.edu/6102587/Dinamika Hubungan_Bilateral_Indonesia-China_Tiongkok_ pada_Era_Pemerintahan_Presiden_Susilo_ Bambang_Yudhoyono_2004-2013. 